\title{
The relationship between emotional intelligence, self-esteem, gender and educational success
}

\author{
Mina Rahimi*
}

Management Group, Amirkabir Institute (University of Applied sciences), Tehran, Iran

\begin{tabular}{l}
\hline C H R O N I C L E \\
\hline Article history: \\
Received January 5, 2016 \\
Received in revised format April \\
15, 2016 \\
Accepted May 20, 2016 \\
Available online \\
May 26, 2016 \\
\hline Keywords: \\
Academic achievement \\
Emotional Intelligence \\
Self-esteem \\
Students
\end{tabular}

\section{Introduction}

One of the primary concerns of teachers and education officials is academic achievement and to take possible actions to prevent academic failure (Needham et al., 2004). Every year, academic failure costs governments and individuals significant amount of money (Josephs, 1992). In Iran, academic failure is also an important issue in the educational system and the government spends significant amount of money on educating people and academic failure wastes a portion of this investment. Educational improvement is told to acquired or learned abilities of people on academic subjects which are measured by standard or teacher-based tests (Navidi, 2003). In general, this means the amount of someone's academic learning that can be studied on various categories such as personal differences and school or educational system (Sajjadi, 2009). So attention to the factors that result educational improvement and prevent of its slumping is very important. One of the factors that have been pointed is Emotional Intelligence (EI), which is counted as one of the newest evolution in the field of understanding the connecting between thought and emotion. This phrase was suggested for the first time by Mayer and Solovey (1997). They believed "Emotional Intelligence, as an ability, is capacity of understanding,

* Corresponding author. Tel.: +989123055829

E-mail address: minarahimi9@yahoo.com (M. Rahimi)

C 2016 Growing Science Ltd. All rights reserved. doi: $10.5267 / \mathrm{j} . \mathrm{msl} .2016 .5 .005$ 
expressing, knowing, using and managing the emotions of you and others". After them Gardner played an important role in completing the theory of EQ with his new model called "Multiple Intelligences". Based on this model there are two major types of intelligence: Intra-intelligence and Inter-intelligence.

In some studies, EQ has positive correlation (Parkar et al., 2004) with educational success and has negative correlation with manners that a break in educational regulations is like impermissible absence. Therefore, the concept of EQ can be used in training situations (Bar-on, 1997). One of the reasons for drawing attention to EQ is that Emotional Intelligence is a better tool for anticipating societal achievements than the traditional concept of intelligence. Those who are better in emotional abilities have greater societal skills, long-term and steadier relations and also can cope with conflicts easily. Also the children with higher emotional skills have more ability to focus on their problems and solutions, which can raise their cognitive skills as well. The studies and researches of Brackett and Solovey (2004), Petrides et al. (2004), Elias and colleagues (2006), Gumora and Arsenion (2002), Ardehshiri (2005) and Besharat (2007) exhibited the relevancy of Emotional Intelligence and training achievements. Checking the relevancy between Emotional Intelligence and educational success is a challenging area and more researches in this context had contradictory findings. Woitaszewski and Aalsma (2004) carried a research on 39 smart teenagers in 2004 and based on the analysis of the survey they recognized that Emotional Intelligence did not play an important role in societal and educational achievements. Also the investigation results of Gholamalilavasani and colleagues (2007), Lalifaz and Asgari (2008), Koohsar and Bonab (2011) and Sobhani and Yuzbashi (2007) displayed that there was no meaning relationship between Emotional Intelligence and educational achievement. Brody and Hall (2008) performed an investigation on emotional differences between girls and boys and reported that girls better than boys are replaced pitched battles by emotional responses and vice versa, boys because no emphasis on describing their feelings, probably unaware of own emotional state and others.

In this regard, Besharat (2007), reported emotional intelligence levels of female students were more than the excitement level of male students and showed that 67 percent of the variance in emotional intelligence success in girls students and 59 percents were associated with academic success of the boys students. But some researches showed that there was no significant difference in total score of emotional intelligence between girls and boys (See for instance Sajjadi, 2009). Self-esteem is one of the factors in academic achievement. Self-esteem comes from satisfaction person of his / her and sense of self-worth. In other words, the purpose of self-esteem is how people think about themselves (Hosseini et al, 2007). According to Thompson (2003), self-esteem is higher in girls than boys. The results of some studies explain the role and importance of emotional intelligence and self-esteem in academic achievement and accordingly, in the present study we test the following hypotheses:

1- There is a relationship between emotional intelligence and academic achievement.

2- There is a relationship between self-esteem and academic achievement.

3- There are some differences between male and female students in terms of emotional intelligence.

4- There are some differences between male and female students in terms of the rate Self-esteem.

\section{Research method}

The recent study is a descriptive - correlation since it examines the relationship between different variables. The statistical society of this research consists of Amirkabir University students (Science and application branch) $(\mathrm{N}=1700)$ in 2015-2016 academic year who were enrolled in undergraduate level. This study selected 300 people between male and female students as the sample group with random method. In the present study to collect data we have used Bar-on Emotional Intelligence Questionnaire and self-esteem pop Questionnaire as well. 
Bar-on Emotional Intelligence Questionnaire consists of 90 questions. The test measures 15 components of emotional intelligence in addition to the overall score are considered. In the Bar-on research (1997) test- retest coefficients are reported 85\% after a month and 75\% after 4 month. In Iran, Zare (2001) achieved $76 \%$ the total average coefficient of internal consistency.

\section{Findings}

To analyze the data, we have used descriptive statistics (frequency, mean and standard deviation) and inferential statistics (correlation coefficient and test-t) with using the SPSS software. Table 1 shows the means and standard deviations for the variables of emotional intelligence, self-esteem and academic achievement of students in the total sample and in terms of gender. In addition, the implementation of Kolmogorov-Smirnov test has indicated that the data were normally distributed and therefore we use Pearson correlation to study the relationships among different components.

Table 1

Means and standard deviations for the variables of emotional intelligence, self-esteem and academic achievement of students in the total sample and in terms of gender

\begin{tabular}{|c|c|c|c|c|c|c|c|c|c|}
\hline \multirow[t]{2}{*}{ Statistics } & \multicolumn{3}{|c|}{ Total sample } & \multicolumn{3}{|c|}{ male } & \multicolumn{3}{|c|}{ Female } \\
\hline & $\mathrm{N}$ & Mean & $\begin{array}{l}\text { Standard } \\
\text { deviation }\end{array}$ & $\mathrm{N}$ & Mean & $\begin{array}{l}\text { Standard } \\
\text { deviation }\end{array}$ & $\mathrm{N}$ & Mean & $\begin{array}{l}\text { Standard } \\
\text { deviation }\end{array}$ \\
\hline $\begin{array}{l}\text { Emotional } \\
\text { Intelligence }\end{array}$ & 300 & 212.4 & 30.3 & 150 & 211.7 & 31.3 & 150 & 215.4 & 30.2 \\
\hline Self-esteem & 300 & 65.3 & 3 & 150 & 62.4 & 2.6 & 150 & 67.2 & 3.2 \\
\hline $\begin{array}{l}\text { Academic } \\
\text { achievement }\end{array}$ & 300 & 16.7 & 1.3 & 150 & 16.2 & 1.2 & 150 & 16.8 & 1.3 \\
\hline
\end{tabular}

As Table 2 indicates correlation between emotional intelligence and academic achievement is $\mathrm{r}=0.035$ and between self-esteem and academic achievement correlation is $r=0.079$. The data indicates that there are not any significant relationships between emotional intelligence and self-esteem and academic achievement when the level of significance is one percent.

Table 2

Correlation matrix of academic achievement, emotional intelligence, self-concept and self-esteem

\begin{tabular}{llccc}
\hline & & 1 & 2 & 3 \\
\hline 1 & Academic achievement & 1 & & \\
2 & Emotional intelligence & 0.035 & 1 & 1 \\
3 & Self-esteem & 0.079 & $0.681^{*}$ & \\
\hline
\end{tabular}

Table 3 indicates there are significant relationships between male and female students in the term of emotional intelligence, self-esteem and academic achievement, which means that self-esteem of female is higher than male. Accordingly, we can say that the third hypothesis is not supported by research and fourth one is confirmed.

Table 3

The results of $t$ test in male and female students in terms of emotional intelligence and self-esteem

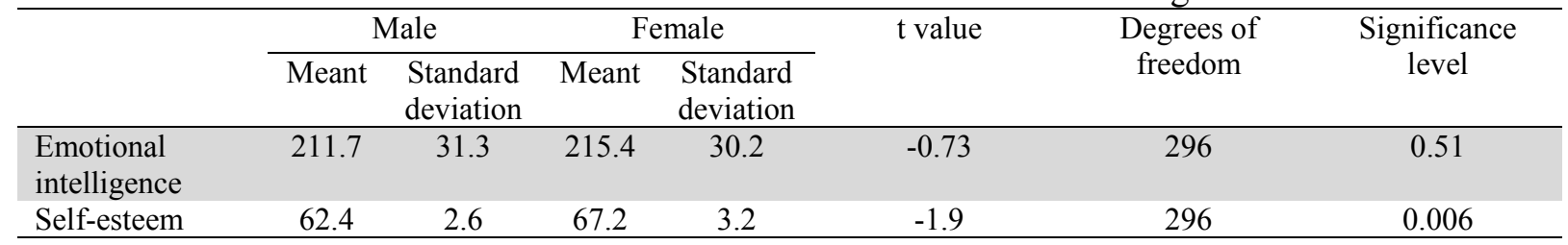

The results of data analysis have shown that emotional intelligence and self-esteem had no significant relationship with achievement. The findings also have shown that emotional intelligence was not 
different between male and female students, but the self-esteem of female students was more than male students. Therefore in considering effective factors in academic achievement just psychological constructs such as emotional intelligence, self- esteem and so on cannot be stressed.

\section{Conclusion}

The aim of this study was to consider relationship between emotional intelligence, self-esteem with academic achievement among female and male students. The first hypothesis test, different between emotional intelligence and academic progress, showed that there was a meaningful relationship between emotional intelligence and academic achievement. The result of this part of the study is consistent with other findings (Gholamalilavasani et al., 2007; Koohsar \& Bonab, 2011; Woitaszewski $\&$ Aalsma, 2004). However, the results of the study are not consistent with findings of Brackett and Salovey (2004), Petrides et al. (2004), Elias and Arnold (2006) and Gumora and Arsenio (2002).

According to our findings, we can say that the structures related to academic achievement are usually related to revenues especially memory capacities and personal learning while emotional intelligence is more related to success of person in interpersonal communications (Koohsar \& Bonab, 2011; Parker et al., 2004) and it seems that academic intelligence has little to do with emotional situation. Many smart people may be nervous in front of natures and nervous tick and the people with high IQ may face several challenges. Emotional intelligence can be a predictor of success, Emotional intelligence cannot be considered the only measure of academic achievement and many factors influence on academic progress.

The results of testing the second hypothesis test, relationship between self-esteem and academic progress, showed no relationship between self-esteem and academic achievement. In explaining the findings of this study one may note the impact of the instruments used in this study.

Previous studies have confirmed the relationship between self-esteem and academic achievement, from self-esteem test (cooper-smith) while for the study of self-esteem in this paper we have used poop. In addition, probably the homogeneity of the sample group had been involved in a significant relationship between self-esteem and academic progress.

In testing the third hypothesis, difference between male and female students in emotional scales, the results have shown a significant difference between men and women in the overall score of emotional intelligence. The finding is consistent with results of Sajjadi (2009), Aghajani et al. (2008), Dibajnia (2005) and Zare (2001). This research also showed that although there was no significant difference in the overall score of emotional intelligence, women in the state of happiness, interpersonal relations, impulse control, responsibility and empathy have more scores.

The results of testing the fourth hypothesis, differences in self-esteem between male and female students, have shown that male and female students were significantly different in terms of self-esteem.

In conclusion it can be said that today, many researchers believe that if a person is emotionally powerful he/she may better face with the challenges of his/her life and we can say that emotion powers us in determining an appropriate emotional responses in the face of everyday events, expanding the scope of insight and positive attitude about the events.

\section{Acknowledgment}

The author would like to thank Amirkabir's students for cordially cooperating in accomplishment of this paper. We are also delighted for constructive comments on earlier version of this paper, which have contributed to the quality and presentation of the paper. 


\section{References}

Aghajani, S., Narimani, M., \& Asiaei, M. (2008). The comparative study of emotional intelligence and self-concept of normal and gifted students.Research on Exceptional Children, 8(3), 317-323.

Ardehshiri, G. (2005). The relationship between emotional intelligence with academic achievement of students. Recent Counseling Researches, 5(18), 97-106.

Bar-On, R. (1997). A measure of emotional and social intelligence in Chicago. Canadian Journal of Behavioral Science, 18, 123-137.

Bar-On, R. E., \& Parker, J. D. (2000). The handbook of emotional intelligence: Theory, development, assessment, and application at home, school, and in the workplace. Jossey-Bass.

Brackett, M. A., \& Salovey, P. (2004). Measuring Emotional Intelligence with Mayer-salovey Caruso Emotional Intelligence Test(MSCEIT); In. Gien Geher(Eds); Measuring Emotional Intelligence: Common Ground and Controversy; Hauppauge NY: Nove Science Publishers.

Besharat, M. A. (2007). Psychometric properties of Farsi version of the Emotional Intelligence Scale41 (FEIS-41). Personality and Individual Differences, 43(5), 991-1000.

Brody, L. R., \& Hall, J. A. (2008). Gender and emotion in context. Handbook of Emotions, 3, 395-408.

Dibajnia, P. (2005). The comparative study of first grade university students to fourth grade of rehabilitation faculty of Shahid Beheshti University. Research in Medicine, 29(3), 231-234 (In Persian).

Elias, M. J., \& Arnold, H. (2006). The educator's guide to emotional intelligence and academic achievement: Social-emotional learning in the classroom. Corwin Press.

Gholamalilavasani, M., Keyvanzadh, M., \& Keyvanzadeh, H. (2007). The relationship among academic activity achievement motive, emotional intelligence and context variables with academic achievement of students. The Journal of Psychology and Education Sciences, 37(1), 99-123 (in Persian).

Gumora, G., \& Arsenio, W. F. (2002). Emotionality, emotion regulation, and school performance in middle school children. Journal of school psychology,40(5), 395-413.

Josephs, R. A., Markus, H. R., \& Tafarodi, R. W. (1992). Gender and self-esteem. Journal of personality and social psychology, 63(3), 391.

Koohsar, A. A. H., \& Bonab, B. G. (2011). Relation between emotional intelligence and quality of attachment in high school administrators.Procedia-Social and Behavioral Sciences, 30, 949-953.

Lalifaz, A., \& Asgari, A. (2008). The ability of emotional intelligence and demographic variables prediction in gifted students academic achievement. Psychology and Education Studies of Mashhad University,9(1), 167-181.

Mayer, J. D., \& Salovey, P. (1997). What is Emotional Intelligence? In P. Salovey \& D. Sluyter (Eds.), Emotional development and emotional intelligence: Educational implications. New York: Basic Books.

Mayer, J. D., Salovey, P., Caruso, D. R., \& Sitarenios, G. (2001). Emotional intelligence as a standard intelligence.

Navidi, A. (2003). The significant study of common and special of former academic function variables academic self-concept and general intelligence in academic achievement prediction of students. The Quarterly Journal of Education, 76, 97-129.

Needham, B. L., Crosnoe, R., \& Muller, C. (2004). Academic failure in secondary school: The interrelated role of health problems and educational context. Social problems, 51(4), 569.

Parker, J. D., Summerfeldt, L. J., Hogan, M. J., \& Majeski, S. A. (2004). Emotional intelligence and academic success: Examining the transition from high school to university. Personality and individual differences, 36(1), 163-172.

Petrides, K. V., Frederickson, N., \& Furnham, A. (2004). The role of trait emotional intelligence in academic performance and deviant behavior at school. Personality and individual differences, 36(2), 277-293.

Sajjadi, S. (2009). The study of emotional intelligence status among university with purpose of curriculum amendment of higher education. Master's thesis, Kashan University. 
Sobhani, M., \& Yuzbashi, A. (2007). Emotional Intelligence and management in Organization. Iran: Tehran, 62-64.

Thompson, J. (2003). The effect of single-sex secondary schooling on women's choice of college major. Sociological Perspectives, 46(2), 257-278.

Woitaszewski, S. A., \& Aalsma, M. C. (2004). The contribution of emotional intelligence to the social and academic success of gifted adolescents as measured by the multifactor emotional intelligence scale-adolescent version.Roeper Review, 27(1), 25-30.

Zare, M. (2001). The study of emotional intelligence contribution in academic achievement. Master's thesis, Tehran psychiatry institute.

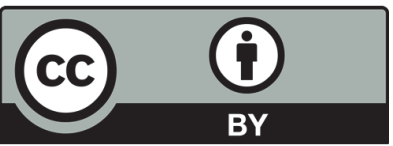

(C) 2016 by the authors; licensee Growing Science, Canada. This is an open access article distributed under the terms and conditions of the Creative Commons Attribution (CC-BY) license (http://creativecommons.org/licenses/by/4.0/). 